УДК 373.5.016:37.091.214-053.5-056.24

DOI: 10.37026/2520-6427-2021-108-4-69-74
Лілія КОВРІГІНА,

кандидат філологічних наук,

завідувач кафедри суспільно-гуманітарних дисииплін

К3 «Житомирський обласний інститут

післядипломної педагогічної освіти»

Житомирської обласної ради,

м. Житомир, Украӥна

ORCID: 0000-0002-6008-7211

e-mail:kovriginalilija@i.ua

\title{
ОСОБЛИВОСТІ РЕАЛІЗАЦІЇ ІНКЛЮЗИВНОГО ПІДХОДУ В СИСТЕМІ ЗАБЕЗПЕЧЕННЯ ЯКОСТІ ОСВІТИ
}

\begin{abstract}
Анотація. У статті окреслено особливості реалізаиії інклюзивного підходу в процедурах та заходах системи забезпечення якості повної загальної середньої освіти. Визначено, щзо впровадження інклюзивного підходу в системі забезпечення якості освіти включає такі чотири етапи: I - засвоєння міжнародного досвіду розвитку інклюзивної освіти (1991-2004); II - урахування в окремих прочедурах забезпечення якості освіти специффіки організаиіі освітнього проиесу для дітей з особливими освітніми потребами (2004-2011); III - початок процесів упровадження інклюзивного підходу в окремі прочедури забезпечення якості освіти (2011-2017); IV - активне впровадження інклюзивного підходу в систему забезпечення якості освіти (2018 - до сьогодні).
\end{abstract}

Доведено, що найповніме інклюзивний підхід реалізується в таких нових процедурах та заходах системи зовнішнього забезпечення якості освіти, як інституиіийнй аудит, сертифікація педагогічних працівників, професійні стандарти вчителів та керівників закладів загальної середньої освіти, а найменш активно - в традиційних процедурах системи забезпечення якості освіти (Державні стандарти освіти, ліцензування освітньої діяльності), зокрема в процедурі атестаиії педагогічних праиівників інклюзивний підхід не простежується взагалі, щзо суперечить сучасним тендениіям розвитку освітньої галузі і вимагає активізачї діяльності відповідних структур щзодо покращення ситуащії, щзо склалася.

Ключові слова: інклюзивний підхід, прочедура, система, забезпечення якості освіти.

\author{
Liliya KOVRIHINA, \\ Candidate of Philological Sciences, \\ Head of the Department \\ of Social Sciences and Humanities, \\ Zhytomyr Regional Institute \\ of Postgraduate Pedagogical Education \\ of Zhytomyr Regional Council, \\ Zhytomyr, Ukraine \\ ORCID: 0000-0002-6008-7211 \\ e-mail: kovriginalilija@i.ua
}

\section{PECULIARITIES OF IMPLEMENTATION OF INCLUSIVE APPROACH IN THE QUALITY ASSURANCE SYSTEM}

\begin{abstract}
The article examines the features of the implementation of inclusive approach in the procedures and measures of the quality assurance system of complete general secondary education.

It has been noted that the current «inclusive» development stage of education for children with special educational needs in Ukraine, characterized by optimization of the network of special educational institutions and the introduction of inclusive education, began in 2011 with the adoption of a government decree on this issue. At the same time, the system of quality assurance in education has been developed in general secondary education institutions of Ukraine since 2017 on the basis of innovative provisions of the updated Law of Ukraine «On Education».

The paper briefly analyzes the features of implementing an inclusive approach in the internal quality assurance
\end{abstract}

system. As well as in such procedures and measures of the external quality assurance system as institutional audit, certification of teachers, professional standards of teachers and principals, monitoring, State educational standards, licensing educational activities, etc.

It is concluded that the introduction of an inclusive approach in the quality assurance system of education is carried out with increasing intensity during four stages. First stage-assimilation of international experience in the development of inclusive education (1991-2004). Second stage-taking into account in certain procedures for ensuring the quality of education the specifics of the organization of the educational process for children with special educational needs (2004-2011). Third stage - the beginning of the processes of implementing an inclusive approach in certain procedures for ensuring the quality of education (2011-2017). Fourth stage - active implementation of an 
inclusive approach in general in the quality assurance system of education (2018 - to present).

It has been shown that the most inclusive approach implemented in such new procedures and measures of the external quality assurance system of education as institutional audit, certification of teachers, professional standards of teachers and heads of general secondary education institutions.

It is emphasized that the least active inclusive approach is implemented in traditional procedures of the education quality assurance system (State educational standards, licensing of educational activities). At the same time the procedure of attestation of teacher's inclusive approach hasn't observed at all. That's contradicts modern trends in education and requires intensification of relevant structures to improve the situation.

Key words: inclusive approach, procedure, system, quality assurance in education.

Постановка проблеми. Європейський вибір України зумовлює реалізацію в країні європейських підходів в організації освіти, зокрема впровадження ідей людиноцентризму, гуманізму, демократизму, формування поваги до прав і свобод людини, нетерпимості до приниження її честі та гідності, дискримінації за будь-якими ознаками тощо.

Важливе місце серед цих інноваційних підходів належить забезпеченню якості освіти, що Законами України «Про освіту» (2017), «Про повну загальну середню освіту» (2020) визначено важливим принципом державної політики у сфері освіти та одним 3 основних завдань освітньої галузі, зокрема повної загальної середньої освіти (далі - 3CO). У зв’язку з цим важливими завданнями для української освіти є розвиток інклюзивного освітнього середовища та організація інклюзивного навчання в закладах освіти (далi-3O).

Відповідно до зазначених підходів в Україні на сучасному етапі активно розбудовується система забезпечення якості освіти, серед основних завдань якої $\epsilon$ гарантування та постійне й послідовне підвищення якості освіти, зокрема й для осіб з особливими освітніми потребами (далі - ООП).

Однак варто зауважити, що на сьогодні особливості реалізації інклюзивного підходу в процедурах і заходах системи забезпечення якості освіти, зокрема повної загальної середньої, досліджено недостатньо.

Аналіз наукових досліджень і публікацій. Вивчення нормативно-правових актів, наукових праць дає підстави стверджувати, що забезпечення якості освіти є одним з основних завдань української освіти та важливим об'єктом дослідження як у теорії, так і в практичній діяльності.

Питанням забезпечення якості освіти присвячено дослідження таких учених, як В. Андрущенко, Н. Бібік, Л. Ващенко, Л. Даниленко, Г. Сгоров, Д. Дзвінчук, Б. Жебровський, Ю. Жук, В. Кремень, О. Локшина, В. Луговий, Т. Лукіна, О. Ляшенко, С. Ніколаєнко, О. Овчарук, В. Огнев'юк, О. Пометун, О. Савченко, А. Сбруєва, М. Слюсаревський, М. Степко, О. Сухомлинська, О. Топузов та ін. Проблеми розвитку інклюзивної освіти аналізували у своїх працях В. Алексєєва, А. Арендарук, О. Барно, В. Болдирєва, О. Гаяш,
I. Гевко, В. Гладуш, Е. Данілавічютє, Т. Дегтяренко, С. Іноземцева, А. Колупаєва, Н. Марковська, Л. Миськів, Ю. Найда, В. Павленко, Т. Сак, Н. Софій, О. Таранченко, О. Федоренко та ін.

Водночас науковцями недостатньо окреслено особливості реалізації інклюзивного підходу в системі забезпечення якості освіти.

Мета статті - проаналізувати особливості реалізації інклюзивного підходу в процедурах та заходах системи забезпечення якості повної загальної середньої освіти.

Виклад основного матеріалу дослідження. Зазначимо, що під інклюзивним підходом науковці розуміють створення таких умов, за яких усі учасники освітнього процесу мають однаковий доступ до освіти (Інститут спеціальної педагогіки і психології імені Миколи Ярмаченка НАПН України, 2021). На думку вчених, сучасний - «інклюзивний» - етап розвитку освіти дітей з ООП в Україні, що характеризується оптимізацією мережі спеціальних 30 та впровадженням інклюзивної освіти, розпочався у 2011 р. та передбачав використання відповідного міжнародного досвіду (Колупаєва, Таранченко, 2016).

Зауважимо, що 6 липня 2010 року були внесені зміни до Закону України «Про загальну середню освіту» (1999), згідно з якими школи отримали право створювати інклюзивні класи для навчання дітей з ООП. Крім того, цього ж року наказом Міністерства освіти і науки України № 912 було затверджено Концепцію розвитку інклюзивного навчання. Відповідно практичне впровадження інклюзивного підходу розпочалося після прийняття постанови Кабінету Міністрів України від 15.08.2011 р. № 872 «Про затвердження Порядку організації інклюзивного навчання в загальноосвітніх навчальних закладах», в якій визначалися шляхи надання освітніх послуг учням з ООП, створення умов для безперешкодного доступу до 30, організації інклюзивних класів, забезпечення шкіл з інклюзивним навчанням необхідними педагогічними кадрами, обладнанням, навчально-методичною літературою тощо.

Стосовно системи забезпечення якості освіти, то варто зазначити, що вперше вимога щодо необхідності iii створення на законодавчому рівні була сформульована в Законі України «Про вищу освіту» (2014). Пізніше ця ідея знайшла свій подальший розвиток у Законах України «Про освіту» (2017) та «Про повну загальну середню освіту» (2020), в яких було визначено основні підходи до створення системи забезпечення якості освіти. Саме із 2017 року розпочалися практичні кроки зі створення означеної системи в галузі $3 \mathrm{CO}$.

Зауважимо, що хоча в згаданих нами вище законах не дається визначення поняття «система забезпечення якості освіти», однак у відповідних статтях законів (ст. 41, 42) наголошується, що складовими цієї системи $\epsilon$ внутрішня система забезпечення якості освіти $($ далі - ВСЗЯО) та система зовнішнього забезпечення якості освіти, яка включає такі інструменти, процедури та заходи, як стандартизація, ліцензування освітньої діяльності, зовнішне незалежне оцінювання результатів навчання (далі - ЗНО), інституційний аудит, моніторинг, атестація та сертифікація педагогічних працівників, громадська акредитація 30 тощо.

Слід зауважити, що такі процедури системи зовнішнього забезпечення якості освіти, як атестація 
педагогічних працівників, стандартизація, ліцензування освітньої діяльності, ЗНО, моніторинг, проводилися в українській освітній галузі й раніше. Із прийняттям у 2011 р. постанови КМ України № 872 інклюзивні підходи стали успішно впроваджуватися в окремих процедурах, а із 2017 р. інклюзія стала активно реалізовуватися загалом у системі забезпечення якості освіти, особливо в таких іiї нових процедурах як інституційний аудит, сертифікація педагогічних працівників тощо.

Проаналізуємо ці процеси детальніше.

У Законі України «Про освіту» (2017) зазначається, що «внутрішня система забезпечення якості освіти, під якою розуміється сукупність умов, заходів і процедур у 3О, що забезпечують результативність освітніх та управлінських процесів, які впливають на ефективність навчання дітей, формування ключових компетентностей школярів та їхній усебічний розвиток» (наказ Міністерства освіти і науки України від 30.11.2020 р. № 1480), має включати створення в 3 О інклюзивного освітнього середовища.

У рекомендаціях із питань формування ВСЗЯО у закладах ЗСО конкретизовано, що процедурами, які забезпечують інклюзивне середовище в 30, можуть бути: організація безбар'єрного простору, розроблення індивідуальних програм розвитку для осіб з ООП, створення ресурсних кімнат, забезпечення необхідним обладнанням медіатек, застосування допоміжних технологій (пристроїв для альтернативної та розширеної комунікації, дисплеїв і принтерів, системи Брайля тощо), організація роботи команди психолого-педагогічного супроводу, проведення просвітницьких заходів 3 метою формування толерантності й недопущення дискримінації та ін. (Пастовенський, Ренькас, 2019).

Таким чином, у нормативно-правових актах і рекомендаціях щодо створення ВСЗЯО освіти шляхи реалізації інклюзивного підходу в зазначених системах окреслено достатньо грунтовно. Однак потрібно також зауважити, що інклюзивний підхід активно реалізовувався в заходах з підвищення якості освітнього процесу із 2011 р., тобто ще до нормативного визначення ВСЗЯО.

Розглянемо детальніше шляхи реалізації інклюзивного підходу в процедурах зовнішнього забезпечення якості освіти.

Однією з процедур, де цей підхід реалізовано на належному рівні, є інституиійний аудит, який передбачає оцінювання освітніх та управлінських процесів 30 (освітнього середовища, системи оцінювання результатів навчання школярів, педагогічної діяльності, управлінських процесів закладу), а також перевірку додержання 30 вимог законодавства в освітній сфері.

Однією з вимог до освітнього середовища 30 є формування інклюзивного, розвивального й мотивуючого до навчання освітнього простору. Для оцінювання означеної вимоги в додатку 1 до Порядку проведення інституційного аудиту 30 передбачено 5 критеріїв та 13 індикаторів (наказ Міністерства освіти і науки України від 09.01.2019 р. № 17).

Для визначення індикаторів відповідно до методики оцінювання освітніх та управлінських процесів 30 під час інституційного аудиту використовуються опитувальний аркуш керівника, запитання для інтерв'ю із заступником директора, анкета для педагогічних працівників, форми вивчення документації, спостереження за освітнім середовищем, за проведенням навчальних занять, зокрема й у режимі онлайн, де серед інших розглядаються також і питання інклюзії (наказ Державної служби якості освіти України від 27.08.2020 p. № 01-11/42).

Наголосимо також, що в процесі перевірки додержання 30 вимог законодавства у сфері ЗСО під час інституційного аудиту в закладі передбачена перевірка забезпечення умов для здобуття освіти осіб із ООП, зокрема $з$ питань дотримання вимог законодавства щодо створення інклюзивних класів, розроблення індивідуальних програм розвитку та навчальних планів дитини з ООП, корекційної спрямованості освітнього процесу для таких дітей, діяльності асистента вчителя та асистента дитини тощо (наказ Державної служби якості освіти України від 06.09.2021 р. № 01-11/57).

Звернемо увагу на те, що на сьогодні в нормативно-правових актах досі не конкретизована ще одна передбачена Законом України «Про освіту» процедура оцінювання якості освітньої діяльності 30 громадська акредитація закладу, яка має здійснюватися на добровільних засадах за запитом 30 акредитованими фаховими громадськими об'єднаннями або юридичними особами. У процесі унормування означеної процедури важливо буде обов'язково враховувати вимоги інклюзивного підходу.

Значна увага звертається на інклюзію ще в одній новій процедурі - сертифікачії педагогічних працівників, що проводиться як зовнішнє оцінювання професійних компетентностей педагогічних працівників. На всіх іiі етапах - незалежного тестування, самооцінювання учасником сертифікації власної професійної майстерності, вивчення практичного досвіду роботи педагогів - передбачено аналіз питань організації інклюзивної освіти.

Зауважимо, що в Програмі незалежного тестування фахових знань та умінь учителів початкової школи, затвердженій наказом МОН України від 14.01.2019 p. № 33, передбачено перевірку фахових знань педагогів 3 питань особливостей навчання та розвитку дітей з ООП, індивідуальних програм розвитку, методів та форм навчання таких учнів, прийомів створення психологічно комфортних умов освітнього процесу, ролі асистента вчителя в інклюзивному навчальному процесі тощо.

У процесі оцінювання професійних компетентностей учасників сертифікації у процесі вивчення їхнього практичного досвіду роботи експерти мають оцінити інклюзивну компетентність педагогів, їхню здатність до роботи 3 дітьми з ООП, формування толерантного ставлення до таких дітей в інших учнів (наказ Державної служби якості освіти України від 18.08.2021 р. № 01-11/55).

Значна увага у професійних стандартах учителя та директора закладу $3 \mathrm{CO}$, які прийняті останнім часом, звертається на інклюзію. Зокрема, у професійних стандартах учителів однією із найбільш важливих визначено інклюзивну компетентність, що передбачає забезпечення педагогічної підтримки осіб з ООП, здатності створювати інклюзивне освітнє середовище, сприятливі умови для кожної дитини залежно від іiі індивідуальних особливостей (наказ Міністерства 
розвитку економіки, торгівлі та сільського господарства України від 23.12.2020 р. № 2736-20).

У професійних стандартах директора закладу $3 \mathrm{CO}$ також виокремлено інклюзивну компетентність, зокрема щодо здатності керівника забезпечувати інклюзивне освітнє середовище, організацію інклюзивного навчання та психолого-педагогічного супроводу учнів з ООП (наказ Міністерства економіки України від 17.09.2021 p. № 568-21).

Стосовно складання здобувачами освіти ЗНО слід зазначити, що в цій процедурі вже з етапу іiї становлення реалізовувався інклюзивний підхід. Так, у постанові КМ України від 25.08.2004 р. № 1095 «Деякі питання запровадження зовнішнього незалежного оцінювання та моніторингу якості освіти» йдеться про те, що особи з ООП мають право на рівний доступ до проходження ЗНО, визначено перелік спеціальних умов, що можуть бути створені для таких осіб у пунктах тестування тощо. Пізніше у Законах України «Про освіту» (2017) та «Про повну загальну середню освіту» (2020) цей підхід було закріплено на законодавчому рівні.

Також не можемо оминути увагою ще однієї процедури системи зовнішнього забезпечення якості освіти - моніторингу. Згідно з наказом МОН України від 22.09.2010 р. № 898 «Про проведення моніторингового дослідження стану інклюзивної освіти в Україні» Інститутом інноваційних технологій і змісту освіти у державі було проведено моніторингове дослідження стану інклюзивної освіти.

У наказі МОН України від16.01.2020 р. № 54 «Про затвердження Порядку проведення моніторингу якості освіти» зазначається, що при проведенні зовнішнього моніторингу заклади, що є учасниками дослідження, мають створювати належні умови для його проведення, зокрема забезпечувати розумне пристосування для дітей з ООП тощо.

Варто наголосити, що в перших Державних стандартах освіти (2000 та 2004 років) про жодну інклюзію, а також осіб з ООП узагалі не йшлося. Не згадується інклюзія ні в постанові КМ України від 23.11.2011 p. № 1392 «Про затвердження Державного стандарту базової і повної загальної середньої освіти», ні в постанові КМ України від 21.02.2018 р. № 87 «Про затвердження Державного стандарту початкової освіти», проте в першому документі наголошується на необхідності толерантного ставлення до людей з особливими фізичними потребами, а в другому - на специфіці роботи 3 дітьми з ООП.

Водночас у постанові КМ України від 30.09.2020 p. № 898 «Про деякі питання державних стандартів», зокрема в додатках до Державного стандарту повної ЗСО, інклюзивність уже згадується неодноразово, передусім у вимогах до обов'язкових результатів навчання учнів в інформатичній, громадянській та історичній освітніх галузях тощо. Отже, в Державних стандартах освіти спостерігається помітний прогрес у реалізації інклюзивного підходу.

У перших постановах КМ України щодо ліцензування освітньої діяльності (від 01.06.1992 р. № 303; від 12.02.1996 р. № 200; від 29.08.2003 р. № 1380 ; від 08.08.2007 р. № 1019) поняття «інклюзія» та «особи з ООП чи інвалідністю» також не згадувалися. I навіть у чинній постанові КМ України від 30.12.015 p. № 1187 «Про затвердження Ліцензійних умов провадження освітньої діяльності» вони з'явилися лише завдяки змінам, внесеним постановою КМ України від 10.05.2018 р. № 347. Так, у зазначеній постанові в організаційних вимогах щодо започаткування та провадження освітньої діяльності зазначається, що ліцензіат має забезпечувати доступність навчальних приміщень для осіб з інвалідністю, безперешкодний доступ до будівлі, класів та ін. У цій постанові також наголошується на необхідності оприлюднення на вебсайтах інформації про виконання умов доступності 30 для навчання осіб з ООП тощо. Тобто після 2017 р. інклюзивний підхід став активніше впроваджуватися і в процедурах ліцензування освітньої діяльності.

Не можемо оминути увагою й однієї з найдавніших процедур (проводиться в Україні у тій чи іншій формі із 1936 р.) забезпечення якості освіти - атестаиії педагогічних працівників. У зв'язку з цим варто зазначити, що і в першому за часів незалежності України Типовому положенні про атестацію педагогічних працівників України (1993), і навіть у чинному Типовому положенні про атестацію педагогічних працівників, затвердженому наказом МОН України від 06.10.2010 р. № 930, ні термін «інклюзія», ні організація роботи 3 дітьми $з$ особливими освітніми потребами чи інвалідністю загалом не згадуються жодного разу. На нашу думку, це суперечить сучасним тенденціям розвитку освіти і потребує відповідного реагування.

Зважаючи на викладене вище, можемо виокремити етапи впровадження інклюзивного підходу в процедурах системи забезпечення якості освіти, що відображено в таблииі.

Таблиия

\section{Етапи впровадження інклюзивного підходу в процедурах системи забезпечення якості освіти}

\begin{tabular}{|c|l|l|}
\hline Період & \multicolumn{1}{|c|}{ Роки } & \multicolumn{1}{c|}{ Характеристика періоду } \\
\hline I & $1991-2004$ & засвоєння міжнародного досвіду розвитку інклюзивної освіти \\
\hline II & $2004-2011$ & $\begin{array}{l}\text { урахування в окремих процедурах забезпечення якості освіти специфіки організації } \\
\text { освітнього процесу для дітей з ООП (ЗНО, моніторинг) }\end{array}$ \\
\hline III & $2011-2017$ & $\begin{array}{l}\text { початок процесів упровадження інклюзивного підходу в окремі процедури забезпечення } \\
\text { якості освіти (процедури ВСЗЯО, Державні стандарти освіти тощо) }\end{array}$ \\
\hline IV & $\begin{array}{l}\text { дог - } \\
\text { до сьогодні }\end{array}$ & $\begin{array}{l}\text { активне впровадження інклюзивного підходу загалом у систему забезпечення якості } \\
\text { освіти (інституційний аудит, сертифікація педагогічних працівників, професійні } \\
\text { стандарти вчителів і директорів закладів ЗСО, моніторинг, Державні стандарти освіти, } \\
\text { ліцензування освітньої діяльності тощо) }\end{array}$ \\
\hline
\end{tabular}


Таким чином, інклюзивна освіта в Україні поступово набирає свого розвитку, що ми можемо прослідкувати від 2004 року, коли інклюзивний рух тільки починав зароджуватися, і дотепер, коли розроблено і затверджено нормативно-правове забезпечення інклюзивного навчання для осіб з особливими освітніми потребами, що дає їм право на здобуття освіти разом із дітьми з типовим розвитком. Це вимагає переорієнтації системи освіти та підготовки педагогічних працівників до умов інклюзивного освітнього простору, що неабияк впливає на якість системи освіти загалом.

Висновки. Здійснений у роботі аналіз дає підстави стверджувати, що процес упровадження інклюзивного підходу в системі забезпечення якості освіти в Україні має певні особливості, серед яких варто виокремити дві найбільш суттєві: 1) такий процес здійснюється 3 наростанням інтенсивності впродовж чотирьох етапів: засвоєння міжнародного досвіду розвитку інклюзивної освіти (1991-2004); урахування в окремих процедурах забезпечення якості освіти специфіки організації освітнього процесу для дітей з особливими освітніми потребами (2004-2011); початок процесів упровадження інклюзивного підходу в окремі процедури забезпечення якості освіти (2011-2017); активне впровадження інклюзивного підходу в систему забезпечення якості освіти (2018 - до сьогодні); 2) найповніше інклюзивний підхід реалізується нині в таких нових процедурах системи зовнішнього забезпечення якості освіти, як інституційний аудит, сертифікація педагогічних працівників, а також у професійних стандартах учителів та керівників закладів ЗСО.

Також варто наголосити, що найменш активно інклюзивний підхід упроваджується в традиційних процедурах системи забезпечення якості освіти (Державні стандарти освіти, ліцензування освітньої діяльності), а в такій процедурі як атестація педагогічних працівників інклюзивний підхід не простежується взагалі, що суперечить сучасним тенденціям розвитку освітньої галузі та потребує адекватного реагування відповідних структур.

Перспективи подальших досліджень убачаємо в розроблені пропозицій щодо реалізації інклюзивного підходу в таких процедурах системи зовнішнього забезпечення якості освіти, як атестація педагогічних працівників, громадська акредитація 30 та ін.

\section{СПИСОК ВИКОРИСТАНОЇ ЛІТЕРАТУРИ}

Інклюзивна освіта. (2021). Інститут спеціальної педагогіки і психологї імені Миколи Ярмаченка Національної академї педагогічних наук Украӥни: вебсайт. URL: http://ispukr.org.ua/?page_id=331 (дата звернення: 04.09.2021).

Колупаєва, А. А., Таранченко, О. М. (2016). Інклюзивна освіта: від основ до практики: монографія. Київ: ТОВ «АТОПОЛ». $152 \mathrm{c}$.

Про затвердження Порядку організації інклюзивного навчання у загальноосвітніх навчальних закладах: постанова Кабінету Міністрів України від 15.8.2011 p. № 872. URL: https://zakon.rada.gov.ua/laws/show/8722011-\%D0\%BF\#Text (дата звернення: 06.09.2021).

Про затвердження Методичних рекомендацій $з$ питань формування внутрішньої системи забезпечення якості освіти у закладах загальної середньої освіти: наказ Міністерства освіти і науки України від 30.11.2020 № 1480. URL: https://zakon.rada. gov.ua/rada/show/v1480729-20\#Text (дата звернення: 06.09.2021).

Пастовенський, О. В, Ренькас, Б. М. (2019). Примірне положення про внутрішню систему забезпечення якості освіти в закладі загальної середньої освіти. Народна освіта. Вип. 3 (39). URL: https://www.narodnaosvita.kiev. ua/?page_id=5974 (дата звернення: 04.09.2021).

Про затвердження Порядку проведення інституційного аудиту закладів загальної середньої освіти: наказ Міністерства освіти і науки України від 09.01.2019 р. № 17. URL: https://zakon.rada.gov.ua/laws/show/z025019\#Техt (дата звернення: 06.09.2021).

Про внесення змін у додатки до наказу Державної служби якості освіти від 09.01.2020 р. № 01-11/1: наказ Державної служби якості освіти України від 27.08 .2020 p. № 01-11/42. URL: https://sqe.gov.ua/wpcontent/uploads/2021/08/01-11-42.pdf (дата звернення: 06.09.2021).

Про затвердження переліку актів законодавства у сфері освіти, дотримання яких перевіряється під час проведення інституційного аудиту та позапланової перевірки закладу загальної середньої освіти: наказ Державної служби якості освіти України від 06.09.2021 p. № 01-11/57. URL : https://sqe.gov.ua/wp-content/ uploads/2021/09/Nakaz-01-11-57.pdf (дата звернення: 06.09.2021).

Про внесення змін до Методики експертного оцінювання професійних компетентностей учасників сертифікації: наказ Державної служби якості освіти України від 18.08.2021 р. № 01-11/55. URL: https://sqe.gov.ua/ wp-content/uploads/2021/08/Metodika ocinyuvannya Sertifikaciya-2021_nakaz_SQE_01-11_55.pdf (дата звернення: 06.09.2021).

Про затвердження професійного стандарту за професіями «Вчитель початкових класів закладу загальної середньої освіти», «Вчитель закладу загальної середньої освіти», «Вчитель з початкової освіти (з дипломом молодшого спеціаліста)»: наказ Міністерство розвитку економіки, торгівлі та сільського господарства України від 23.12.2020 р. № 2736-20. URL: https://zakon.rada. gov.ua/rada/show/v2736915-20\#Text (дата звернення: 06.09.2021).

Про затвердження професійного стандарту «Керівник (директор) закладу загальної середньої освіти»: наказ Міністерства економіки України від 17.09.2021 p. № 56821. URL: https://mon.gov.ua/storage/app/media/ news/2021/09/22/Nakaz-568-zatverdzh.standartu. keriv.22.09.pdf (дата звернення: 06.09.2021).

\section{REFERENCES}

Inkliuzyvna osvita [Inclusive education]. Instytut spetsialnoi pedahohiky i psykholohii imeni Mykoly Yarmachenka Natsionalnoi akademii pedahohich nykhnauk Ukrainy: vebsait. URL: http://ispukr.org.ua/?page_id=331 (data zvernennia: 04.09.2021). [in Ukrainian].

Kolupaieva, A. A., Taranchenko, O. M. (2016). Inkliuzyvna osvita: vid osnov do praktyky [Inclusive education: from the basics to practice]: monohrafiia. Kyiv: TOV «ATOPOL». 152 s. [in Ukrainian]. 
Pro zatverdzhennia Poriadku orhanizatsii inkliuzyvnoho navchannia u zahalnoosvitnikh navchalnykh zakladakh [On the statement of the Order of the organization of inclusive training in comprehensive educational institutions]: postanova Kabinetu Ministriv Ukrainyvid 15.08. 2011 r. № 872. URL: https://zakon.rada.gov.ua/ laws/show/872-2011-\%D0\%BF\#Text (data zvernennia: 06.09.2021). [in Ukrainian].

Pro zatverdzhennia Metodychnykh rekomendatsii z pytan formuvannia vnutrishnoi systemy zabezpechennia yakostiosvity u zakladakh zahalnoi serednoi osvity [On the statement of methodical recommendations concerning formation of internal system of maintenance of education quality in general secondary education institutions]: nakaz Ministerstva osvity i nauky Ukrainy vid 30.11.2020 r. № 1480. URL: https://zakon.rada.gov.ua/rada/show/ v1480729-20\#Text (data zvernennia: 06.09.2021). [in Ukrainian].

Pastovenskyi, O. V., Renkas, B. M. (2019). Prymirne polozhennia pro vnutrishniu systemu zabezpechennia yakosti osvity v zakladi zahalnoi serednoi osvity [Approximate provision on the internal security system of quality assurance of education in general secondary education institutions]. Narodna osvita. Vyp. 3 (39). URL: https://www. narodnaosvita.kiev.ua/?page_id=5974 (data zvernennia: 04.09.2021). [in Ukrainian].

Pro zatverdzhennia Poriadku provedennia instytutsiinoho audytu zakladiv zahalnoi serednoi osvity [On the statement of the procedure for carrying out institutional audit of general secondary education institutions]: nakaz Ministerstva osvity i nauky Ukrainy vid 09.01.2019 r. № 17. URL: https:// zakon.rada.gov.ua/laws/show/z0250-19\#Text (data zvernennia: 06.09.2021). [in Ukrainian].

Pro vnesennia zmin u dodatky do nakazu Derzhavnoi sluzhby yakosti osvity vid 09.01.2020 № 01-11/1 [On modification of the Methodology of expert assessment of professional competencies of certification participants]: nakaz Derzhavnoi sluzhby yakosti osvity Ukrainy vid 27.08.2020 r. № 01-11/42. URL: https://sqe.gov.ua/wp-content/uploads/2021/08/01-11-42.pdf (data zvernennia: 06.09.2021). [in Ukrainian].
Pro zatverdzhennia pereliku aktiv zakonodavstva u sferi osvity, dotrymannia yakykh pereviriaietsia pid chas provedennia instytutsiinoho audytu ta pozaplanovoi perevirky zakladu zahalnoi serednoi osvity [On the statement of the list of acts of the legislation in the field of education which observance is checked during carrying out institutional audit and unscheduled inspection of general secondary education institutions]: nakaz Derzhavnoi sluzhby yakosti osvity Ukrainy vid 06.09.2021 r. № 01-11/57. URL: https://sqe. gov.ua/wp-content/uploads/2021/09/Nakaz-01-11-57.pdf. (data zvernennia: 06.09.2021). [in Ukrainian].

Pro vnesennia zmin do Metodyky ekspertnoho otsiniuvannia profesiinykh kompetentnostei uchasnykiv sertyfikatsii [On the modification of the methodology of expert assessment of professional competencies of certification participants]: nakaz Derzhavnoi sluzhby yakosti osvity Ukrainy vid 18.08.2021 r. № 01-11/55. URL: https://sqe.gov.ua/ wpcontent/uploads/2021/08/Metodika_ocinyuvannya_Sertifikaciya-2021_nakaz_SQE_01-11_55.pdf(data zvernennia: 04.11.2021). [in Ukrainian].

Pro zatverdzhennia profesiinoho standartu za profesiiamy «Vchytel pochatkovykh klasiv zakladu zahalnoi serednoi osvity», «Vchytel zakladu zahalnoi serednoi osvity», «Vchytel z pochatkovoi osvity (z dyplomom molodshoho spetsialista)» [On the statement of the professional standard on professions «The teacher of initial classes of establishment of general secondary education», «The teacher of establishment of general secondary education», "The teacher on primary education (with the diploma of the junior specialist)»]: nakaz Ministerstvo rozvytku ekonomiky, torhivli ta silskoho hospodarstva Ukrainy vid 23.12.2020 r. № 2736-20. URL: https://zakon.rada.gov.ua/rada/show/v273691520\#Text (data zvernennia: 06.09.2021). [in Ukrainian].

Pro zatverdzhennia profesiinoho standartu «Kerivnyk (dyrektor) zakladu zahalnoi serednoi osvity» [On the statement of the professional standard «The head (director) of establishment of general secondary education»]: nakaz Ministerstva ekonomiky Ukrainy vid 17.09.2021 r. № 568-21. URL: https://mon.gov.ua/storage/app/media/ news/2021/09/22/Nakaz-568-zatverdzh.standartu.keriv.22.09.pdf (data zvernennia: 06.09.2021). [in Ukrainian].

Дата надходження до редакиіï: 05.10.2021 p. 